\title{
Polychaete abundance and dispersion patterns in mussel beds: a non-trivial 'infaunal' assemblage on a Pacific South American rocky shore
}

\author{
Mutsunori Tokeshi* \\ School of Biological Sciences, Queen Mary and Westfield College, University of London, Mile End Road, \\ London E1 4NS, United Kingdom \\ and \\ Laboratorio de Zoología Marina, Facultad de Ciencias Biológicas, Universidad Nacional Mayor de San Marcos, \\ Apartado 1898, Lima-100, Perú
}

\begin{abstract}
Patterns of abundance and spatial dispersion were analysed in an assemblage of polychaetes associated with mussel beds in a wave-exposed rocky intertidal habitat on the Pacific coast of subtropical South America. Mussel beds were made up of 2 zones in the intertidal, the lower, more extensive zone formed by Semimytilus algosus and the upper by Perumytilus purpuratus. Total polychaete density in the Semimytilus habitat was in the range of 18800 to 36300 ind. $\mathrm{m}^{-2}$, comparable to some high values recorded for polychaete communities in soft sediments. This indicates that musselbed environments on hard substrata are not a marginal but major habitat for polychaetes (free-ranging forms in particular) on the predominantly rocky coast of western South America. Populations of 6 taxa (Pseudonereis, Halosydna, Lumbrineris, Scoloplos, Mediomastus and Typosyllis) demonstrated moderate seasonal fluctuations, with numbers generally low in austral winter and reaching maxima in spring/summer. Numerically, Typosyllis was the most abundant taxon, accounting for 52 to $71 \%$ of all individuals. All the taxa showed a contagious (aggregated) dispersion, with the deposit feeder Medionastus demonstrating the strongest aggregation and largest fluctuations over a year. Another deposit feeder with limited mobility, Scoloplos, also demonstrated relatively strong aggregation. Iwao's $\dot{m}-m$ regression analysis revealed that mean crowding measure was linearly related to mean density in Pseudonereis, Halosydna, Lumbrineris and Scoloplos, with the highest value of slope $\beta(2.06)$ for Scoloplos, while no relation was evident in Mediomastus and Typosyllis. Density was generally lower in the upper Perumytilus habitat, in particular for the 2 free-ranging taxa Halosydna and Typosyllis, while the free ranger Syllis had a higher density in the Perumytilus than in the Semimytilus bed. All taxa were more strongly aggregated in the Perumytilus than in the Semimytilus habitat, probably reflecting the variability and more patchy occurrence of favourable microhabitats and available resources in the former. Among the 5 taxa that occurred in abundance in both Semimytilus and Perumytilus habitats, the less mobile deposit feeder Scoloplos had the highest degree of contagion indicating its patchy, aggregated distribution patterns, while the predaceous, completely free-ranging Halosydna demonstrated a relatively weak aggregation. Overall, the lack of regular dispersion patterns and the consistent occurrence of contagious distributions suggested that polychaetes associated with mussel beds did not demonstrate territorially based interactions as seen in some sessile, tubedwelling species. Complex, coarse-grained habitat structures of mussel beds support high abundances and species richness of polychaetes, allowing the expression of taxa-specific patterns of dispersion as a result of interactions beween behaviours and environmental conditions.
\end{abstract}

KEY WORDS: Polychaetes $\cdot$ Abundance $\cdot$ Dispersion patterns $\cdot$ Mussel beds $\cdot$ Rocky shores

\section{INTRODUCTION}

Pattern of spatial dispersion is an important aspect in the population ecology of an organism (Pielou 1977, Begon et al. 1990). Dispersion pattern is considered to

•E-mail:m.tokeshi@qmw.ac.uk. reflect an organism's behavioural response to a range of biotic/abiotic environmental factors, often mediated by some stochasticity in dispersal processes. Therefore, comparative studies of dispersion patterns among different species may help clarify differences in taxaspecific behaviours and patterns of resource utilization. 
Dispersion patterns in polychaetes, one of the most abundant benthic taxa in marine environments, have been investigated intensively, particularly in softbottom environments (Woodin 1974, Jumars 1978 , Eckman 1979, Reise 1979, Levin 1981, Wilson 1981, Anderson \& Kendziorek 1982, Volckaert 1987, Thrush et al. 1989). Their abundances and distributions on hard substrates, on the other hand, have largely been under-investigated. On marine rocky shores, primary rock surfaces are frequently occupied by dense populations of mytilid bivalves (cf. Seed 1976. Suchanek 1985, Seed \& Suchanek 1992) which form an intricate matrix of 3-dimensional habitat structures that can be inhabited by polychaetes and other organisms (Suchanek 1979, 1985, Tsuchiya \& Nishihira 1985, 1986, Tsuchiya \& Bellan-Santini 1989, Tokeshi \& Romero 1995a). These organisms constitute a unique assemblage, as the majority of taxa cannot exist with out the protection provided by mussel beds on an exposed shore (Tokeshi \& Romero 1995a). Although a considerable body of information exists on the dynamics of mussel beds in both intertidal (Dayton 1971, Paine 1971, 1974, Paine \& Levin 1981) and subtidal (Dean \& Hurd 1980, Schoener \& Schoener 1981. Chalmer 1982, Greene \& Schoener 1982, Okamura 1986) systems, few studies have investigated the spatial patterns and interspecific relationships of species coexisting in these mussel-matrix habitats (Tsuchiya \& Nishihira 1985, 1986, Tokeshi et al. 1989b).

The present study deals with an assemblage of polychaetes which are the dominant component of musselassociated faunas on a subtropical South American rocky shore (Tokeshi \& Romero 1995a). Rocky shores on the Pacific coast of South America are often extensively colonised by 2 mussel species, Semimytilus algosus (Gould) and Perumytilus purpuratus (Lamarck) (Tokeshi et al. 1989b). S. algosus occurs primarily at low to middle latitudes along the Pacific coast of South America, while $P$. purpuratus is more common in cold temperate waters of Chile and southern Argentina. On the Pacific coast, $P$. purpuratus increases in proportion towards higher latitudes and eventually forms a single mussel zone in central and southern Chile (Alveal et al. 1973, Castilla 1981). In the Peruvian intertidal where the 2 species coexist, they demonstrate distinct zonation with $S$. algosus occupying a lower intertidal position and often forming a more extensive zone than $P$. purpuratus (Paredes 1974, Tokeshi et al. 1989a, b) Though their centre of distribution is in the intertidal rather than in the subtidal, $S$. algosus sometimes extend to the subtidal where they may attain large size $(>7 \mathrm{~cm}$; individuals in the intertidal rarely exceed $4 \mathrm{~cm}$ in length) .

The objective of the present study was to elucidate patterns of spatial dispersion and abundance of a poly- chaete assemblage associated with Semimytilus and Perumytilus beds, with some emphasis on the former habitat. Analyses focused on variation in spatial patterns and abundances among different taxa, particularly free-ranging species which were abundant in the mussel beds. Comparisons were made between the 2 mussel beds which provided different habitat conditions to associated faunas.

\section{MATERIALS AND METHODS}

Study site. The study was conducted on an exposed rocky shore at the outer edge of a small bay in Ancón $\left(11^{\circ} 46^{\prime} \mathrm{S}, 77^{\circ} 12^{\prime} \mathrm{W}\right)$, central Peru. At the study site, Semimytilus algosus occupied a wide expanse in the mid/lower intertidal and formed a thick layer $(7$ to $10 \mathrm{~cm}$ ) of mussels which were loosely held together by byssus threads. Perumytilus purpuratus more often occurred as a single or double layer of mussels in the upper intertidal, less than $4 \mathrm{~cm}$ thick and tightly attached to the rock platform. S. algosus did not extend into the sublittoral where rock surfaces were dominated by calcareous algae accompanied by an anthozoan, Phymactis clematis (Drayton), and an echinoid, Tetrapigus niger. In the upper littoral, apart from $P$. purpuratus, primary rock surfaces were colonised only by a cirriped, Notochthamalus scabrosus (Darwin), a gastropod, Littorina peruviana (Lamarck), and a red alga, Ahnfeltia sp., all tolerant of desiccation and heat. For further descriptions of this habitat and the ecology of selected taxa, see Paredes (1974), Paredes \& Tarazona (1980), Tokeshi $(1989,1991)$, Tokeshi et al. (1989a, b) and Tokeshi \& Romero $(1995 \mathrm{a}, \mathrm{b})$.

Sampling methods. Because the Semimytilus bed was more extensive than that formed by Perumytilus, different sampling regimes were established for the 2 beds. The mussel beds were mapped to facilitate random sampling For the Semimytilus purpuratus bed, 15 replicate sampling units $(10 \times 10 \mathrm{~cm}$ quadrats $)$ were taken bimonthly in 1986. All the mussels and associated organisms within a metal quadrat were removed from the rock platform using a knife and spatula. Small crevices and depressions on the rock surface were carefully scraped to collect all of the organisms. When the sampling did not proceed smoothly and/or surf intervened, that sample was discarded and another taken; this precaution was taken in order to avoid biased sampling or loss of certain organisms, particularly free-ranging species. For the Perumytilus bed, 10 sampling units of the same dimension were taken in March July and November 1986. All the samples were kept in polythene bags with 7 to $10 \%$ formalin. In the laboratory mussel clumps were thoroughly separated and, af ter being washed through a sieve of $250 \mu \mathrm{m}$ aperture, 
animals living in the interstitial space formed by byssus threads were sorted out. All the polychaete individuals were identified to species where possible (but at least to genus level) and counted.

Data analysis. Dispersion patterns of different polychaete taxa were analysed using (1) Morisita's index of dispersion $I_{\delta}$ (Morisita 1959,1962 ) and (2) the $\dot{m}-m$ regression method (Iwao 1968, 1972). $I_{\delta}$ is given as

$$
I_{\delta}=\mathrm{n}\left(\sum x^{2}-\sum x\right) /\left[\left(\sum x\right)^{2}-\sum x\right]
$$

where $x$ is the number of individuals in a quadrat and $\mathrm{n}$ is the number of sampling units. This index assumes unity (1.0) for a random distribution, over 1.0 for a contagious distribution, and less than 1.0 for a regular distribution. Departure from randomness was assessed by calculating,

$$
\chi^{2}=I_{\delta}\left(\sum x-1\right)+\mathrm{n}-\sum x
$$

Morisita's index generally gives a value close to the variance to mean ratio $(I)$, another measure of dispersion in wicle use. The latter index was also calculated, but the results were reported for Morisita's index only since no additional information was gained from considering $I$.

Iwao (1968, 1972) suggested that Lloyd's (1967) mean crowding measure $\dot{m}$ is related to mean density $m$, thus,

$$
\dot{m}=\alpha+\beta m
$$

where $\alpha$ and $\beta$ are parameters. This regression method is useful for examining the dispersion patterns across a range of population densities and considered to have a theoretical advantage over the widely known Taylor's power law method (Tokeshi 1995). Since this method requires a series of values of $\dot{m}$ and $m$, only the data from the Semimytilus algosus bed were used for this analysis.

Because Morisita's index is apparently influenced by $\mathrm{n}$ and $\mathrm{n}$ was different for samples from the Semimytilus bed ( $\mathrm{n}=15$ ) and from the Perumytilus bed ( $\mathrm{n}=10$ ), the following 'Jack-knife' type procedure (cf. Zahl 1977) was adopted for a standardised comparison of $I_{\delta}$ between the 2 habitats. From the Semimytilus sample, 10 out of 15 sampling units may be taken and an $I_{\delta}$ value calculated. There is a total of $3003\left(=\left(\begin{array}{c}15 \\ 10\end{array}\right)\right)$ different combinations of 10 units, each of which yields $I_{\delta}$. All of these 3003 combinations were formed and resultant values were compared with the single observed value for the Perumytilus bed, thus all standardised for $\mathrm{n}=10$. If either less than 75 or more than $2928(2.5 \%$ each, 2-tailed test) of derived values for the Semimytilus bed were smaller than the observed $I_{\delta}$ for the Perumytilus bed, $I_{\delta}$ for the Semimytilus bed was considered to be significantly larger/smaller (i.e. stronger/ weaker aggregation, respectively) than that for the Perumytilus bed $(\mathrm{p}<0.05)$.

\section{RESULTS}

\section{Polychaete fauna and abundances}

Polychaete taxa observed in the present study include Pseudonereis gallapagensis Kinberg, Nereis callaona (Grube) and N. grubei (Kinberg), Halosydna johnsoni (Darboux), Lumbrineris tetraura (Schmarda) and L. annulata Hartmann-Schröder, Steggoa negra Hartmann-Schröder, Scoloplos sp., Mediomastus branchiferus Hartmann-Schröder, Syllis gracilis Grube, Typosyllis magdalena (Wesenberg-Lund) and T. prolixa (Ehlers). Nereis spp. and Steggoa negra occurred in low numbers ( $<3$ individuals per sampling unit) throughout the year and were therefore excluded from the analysis of dispersion pattern. Similarly, the occurrence of Phragmatopoma moerchi Kinberg, which was sometimes observed to construct its sand-tube attached to mussel shells, was sporadic and could not be included in the present analysis. Because of taxonomic uncertainties of specific identifications, particularly of small individuals, and also the possibility of more unidentified species in some genera, data analyses were carried out using 7 generic categories: Pseudonereis (Nereidae), Halosydna (Polynoidae), Lumbrineris (Lumbrineridae), Scoloplos (Orbiniidae), Mediomastus (Capitellidae), Typosyllis (Syllidae) and Syllis (Syllidae). These categories serve as a convenient classification of ecomorphological characteristics of abundant polychaetes in mussel beds, all belonging to separate families (except the last two, which are both Syllidae).

Total polychaete density in the Semimytilus bed fluctuated between 18800 to 36300 ind. $\mathrm{m}^{-2}$ (Fig. 1), with the lowest value recorded in austral winter (July) and the highest in early spring (September), the latter due largely to the recruitment of juveniles. Six polychaete

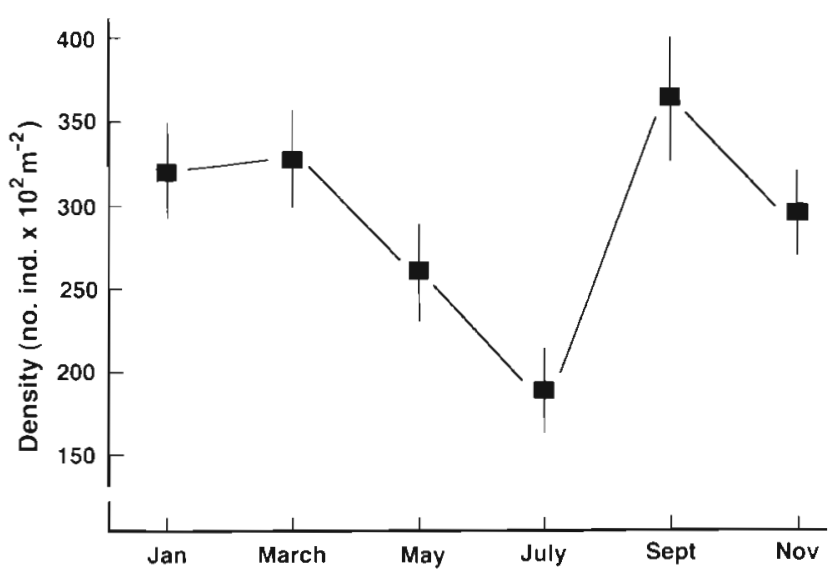

Fig. 1. Variation in total polychaete density (mean $\pm 1 \mathrm{SE}$ ) in a Semimytilus bed 


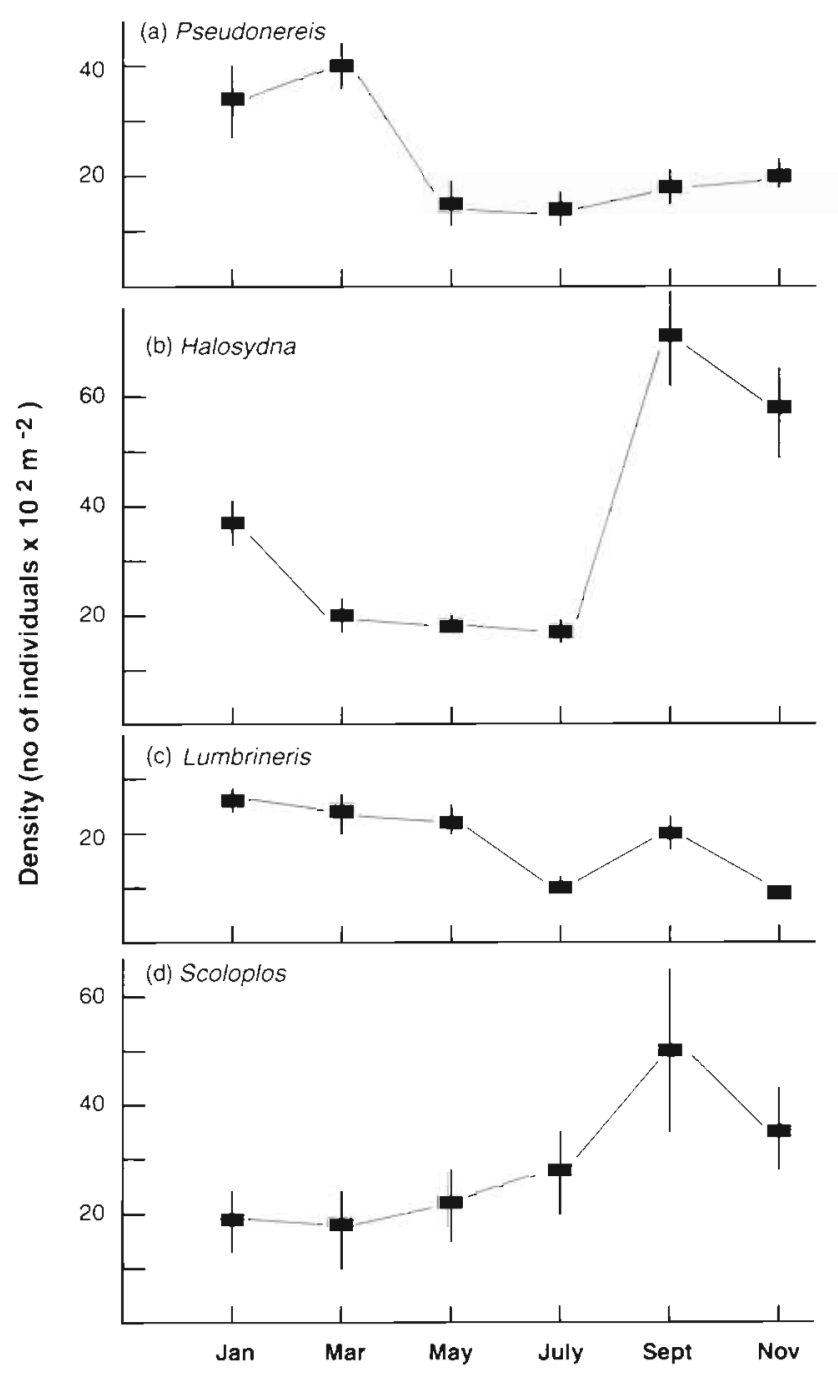

taxa (Syllis was excluded from analysis due to low occurrences in the Semimytilus habitat) showed some discernible patterns of population fluctuations (Fig. 2), with Typosyllis always attaining highest densities amongst them (13400 to $21000 \mathrm{~m}^{-2}, 52$ to $71 \%$ of the entire polychaete assemblage). Pseudonereis (Fig. 2a) and Typosyllis (Fig. 2f) demonstrated the highest densities in austral summer (January to March) and the lowest in austral winter (July). Halosydna (Fig. 2b) also had its lowest density in July, but this increased rapidly in austral spring (September to November) with a maximum of $7100 \mathrm{~m}^{-2}$. Scoloplos showed a seasonal pattern similar to Halosydna, with density reaching its maximum $\left(5000 \mathrm{~m}^{-2}\right)$ in spring (September). Both Lumbrineris and Mediomastus showed a similar pattern, with a fluctuating but gradually declining density during the study period; it should be pointed out here, however, that in the case of Lumbrineris the November sample contained many fragmented bodies of small individuals, most probably of new recruits, which could
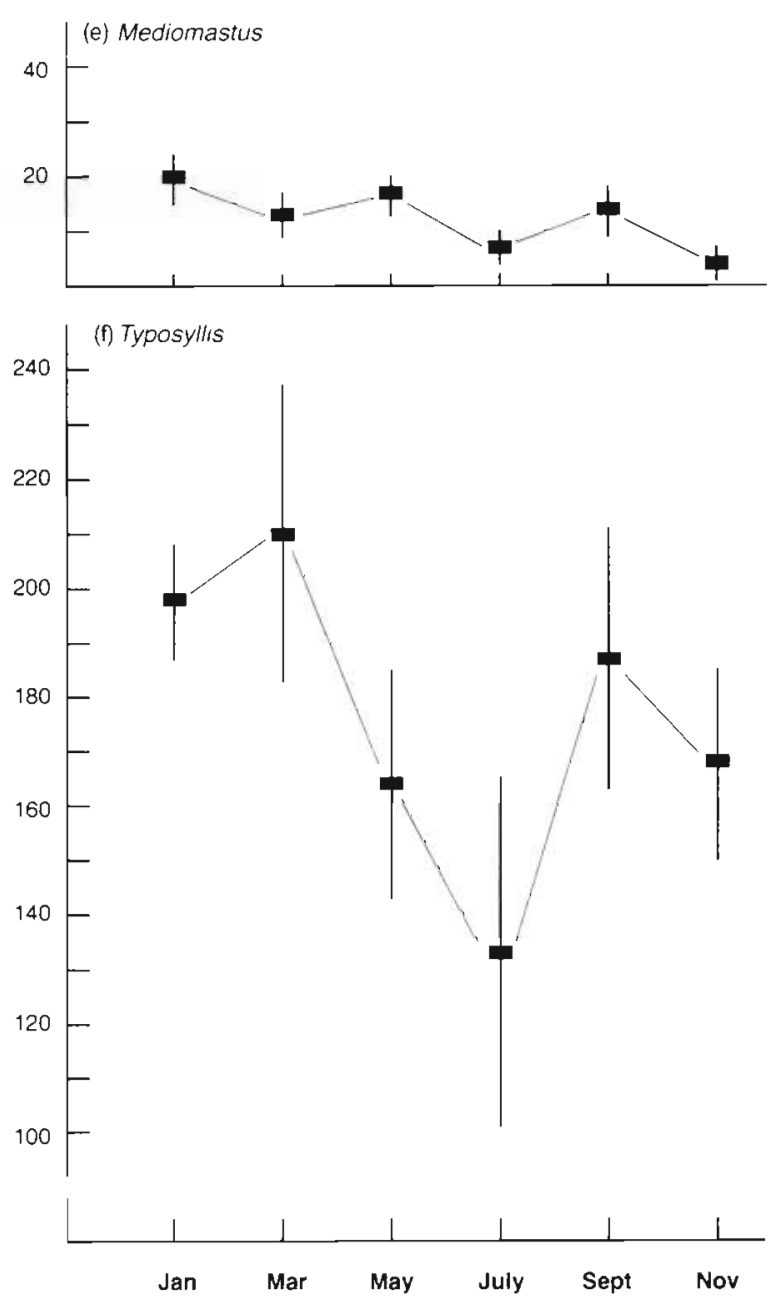

Fig. 2. Variation in density (mean $\pm 1 \mathrm{SE}$ ) of 6 polychaete taxa in a Semimytilus bed

not be counted efficiently. Therefore, the density value for Lumbrineris in November is underestimated, and its general trend is considered to be an increasing population density in spring.

The relationship between annual mean density and maximum body size (average dry weight biomass of 10

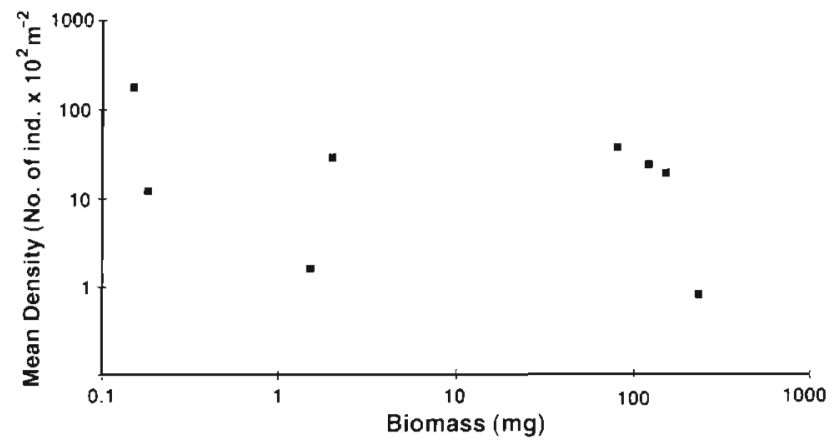

Fig. 3. Relationship between mean density and maximum individual biomass in a polychaete assemblage 
largest individuals) for different taxa in this polychaete assemblage (including Steggoa negra) was analysed to see whether there was an allometric relation between density and body size (Fig. 3). Mean density spanned 2 orders of magnitude and biomass slightly over 3 orders of magnitude. Despite an appearance of a weak, negative relation, this was not statistically significant $(p>$ 0.05 ), indicating that body size does not influence the relative abundances of polychaete taxa.

\section{Dispersion patterns}

Values of the Morisita's index of dispersion $I_{\delta}$ for 6 polychaete taxa in the Semimytilus habitat were mostly in the range of 1.0 to 3.0 (Fig. 4), all indicating a significant $(\mathrm{p}<0.05)$ departure towards contagious (aggregated) distribution, though the magnitude of contagion was variable among taxa. The largest temporal variation was seen in Mediomastus, with the highest value (8.94) of $I_{\delta}$ recorded in November and the lowest (1.44) $I_{\delta}$ recorded in May. Values for Scoloplos were also high, frequently exceeding 2.0 and in the range of 1.61 to 2.98 . Somewhat lower variability was observed for Pseudonereis and Typosyllis, the highest $I_{\delta}$ being 1.97 in May and 1.81 in July, respectively. The lowest temporal variability in $I_{\delta}$ was observed for Halosydna and Lumbrineris, the former in the range of 1.07 to 1.32 and the latter 1.03 to 1.48 . Thus, these 2 taxa were, on average, less strongly aggregated than others.

Fig. 5 shows Morisita's $I_{\delta}$ plotted against density for all the taxa, pooling the bimonthly data. There appears to be a negative relationship between the 2 variables, but this was statistically not significant ( $\mathrm{p}=0.118$ ).

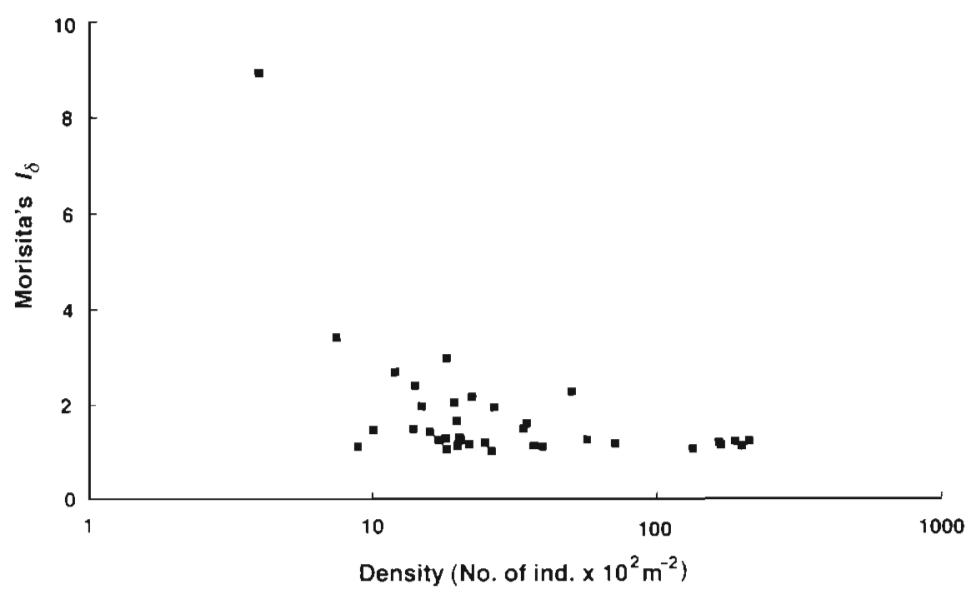

Fig. 5. Relationship between mean density and Morisita's index of dispersion $\left(I_{\delta}\right)$ in a polychaete assemblage

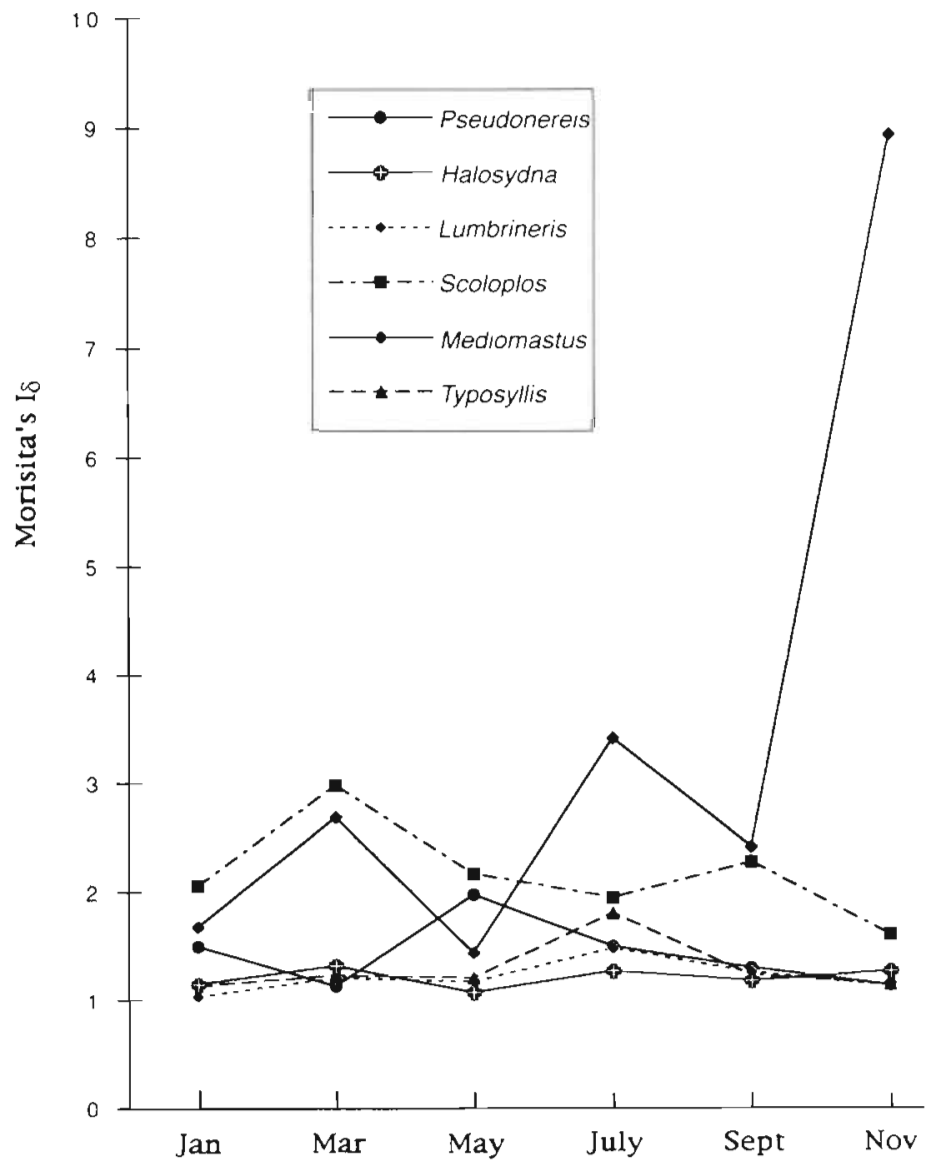

Fig. 4. Variation in Morisita's index of dispersion $\left(I_{\delta}\right)$ of 6 polychaete taxa (see 'Materials and methods')

An analysis with the $\dot{m}-m$ regression method revealed variable dispersion patterns among polychaete taxa (Fig. 6). Four taxa demonstrated a significant regression between $\dot{m}$ and $m$, with the proportion of the variance accounted for $\left(\mathrm{r}^{2}\right)$ ranging from $78 \%$ (Pseudonereis, Fig. 6a) to 99\% (Halosydna, Fig. 6b). Slope $\beta$ was highest in Scoloplos ( $\beta=$ 2.06 ) and lowest in Lumbrineris $(\beta=1.03)$. In contrast, no significant relationship between $\dot{m}$ and $m$ was found in Mediomastus (Fig. 6e) and Typosyllis (Fig. 6f), indicating that mean crowding measure was independent of mean density in these taxa.

\section{Comparison between Semimytilus and Perumytilus habitats}

Abundances of different polychaete taxa varied between the lower Semimytilus and the upper Perumytilus habitats (Fig. 7). It is possible to recognise 5 different types: (1) no significant difference in density between the 

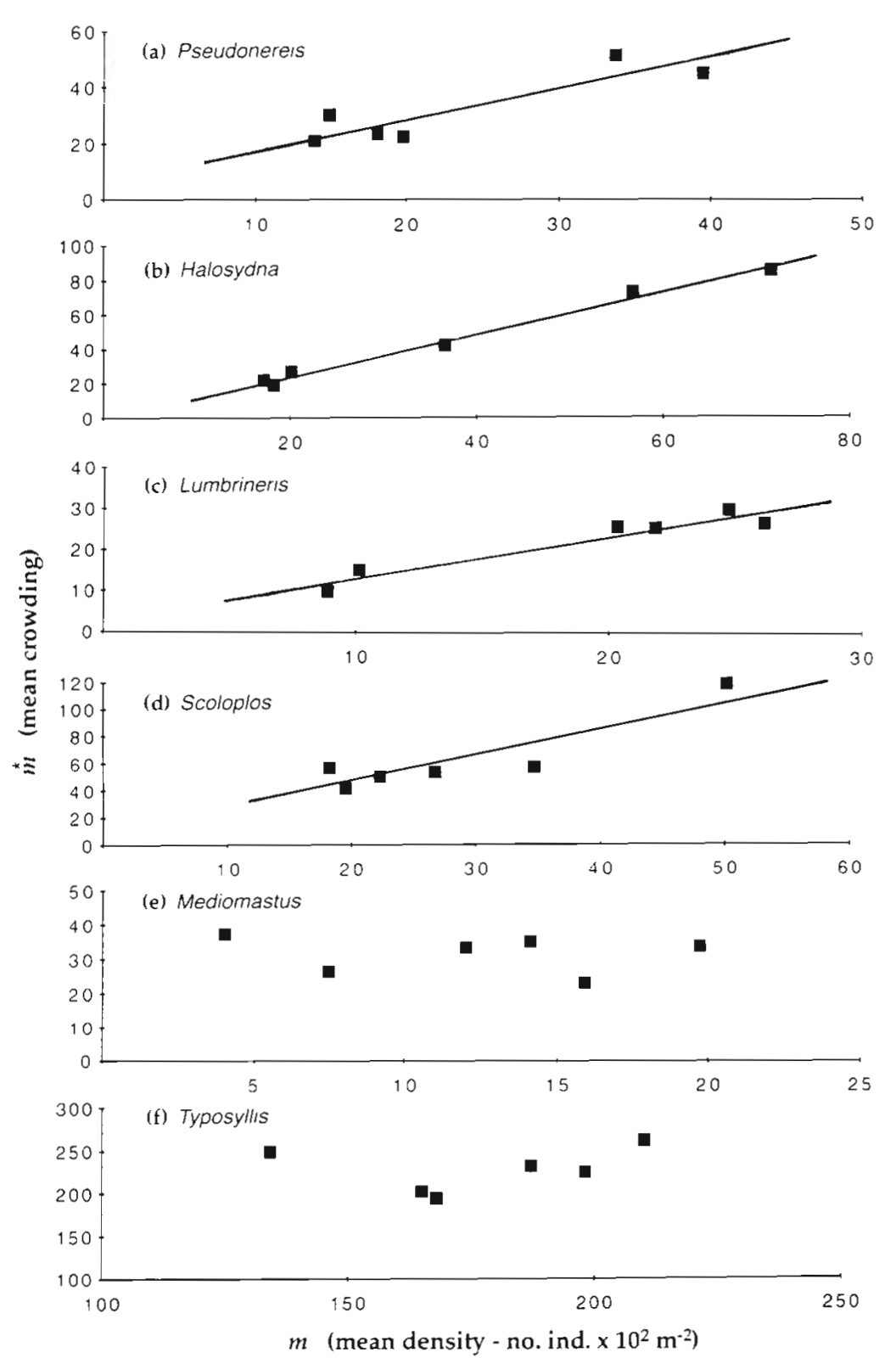

Fig. 6. Relationship between mean density and mean crowding in 6 polychaete taxa. Regression line is shown only where the relationship is significant (a) $\dot{m}=7.74+1.06 \mathrm{~m} \mathrm{r}^{2}$ (\% of variance accounted for by linear regression) $=78, \mathrm{p}<0.05 ;$ (b) $\dot{\mathrm{m}}=0.196+1.22 \mathrm{~m}, \mathrm{r}^{2}=99, \mathrm{p}<0.001 ;$ (c) $\dot{\mathrm{m}}=3.29+$ $1.03 \mathrm{~m}, \mathrm{r}^{2}=92, \mathrm{p}<0.01 ;$ (d) $\dot{m}=4.17+2.06 \mathrm{~m}, \mathrm{r}^{2}=81, \mathrm{p}<0.05 ;(\mathrm{e}) \mathrm{r}^{2}=42, \mathrm{~ns}$; (f) $r^{2}=52, n s$ (i.e. no fixed pattern), e.g. Scoloplos (Fig. 7d). Differences between the 2 beds seem less pronounced in austral winter (July).

Within the Perumytilus bed different polychaete taxa demonstrated different dispersion patterns, with $I_{\delta}$ ranging from 1.10 for Typosyllis in March to 2.27 for Scoloplos in November (Table 1). Scoloplos had the highest $I_{\delta}$ among all the taxa on all 3 occasions, clearly indicating its strongly contagious distribution in this habitat. Lumbrineris also had relatively high values of $I_{\delta}$, second only to Scoloplos in March and November. Typosyllis had the lowest values overall, indicating that it was less strongly aggregated than other taxa. Temporally, 4 taxa (Pseudonereis, Halosydna, Typosyllis and Syllis) had lowest values of $I_{\delta}$ in March (late summer).

Comparison of dispersion patterns between the Semimytilus and Perumytilus habitats was feasible for 5 taxa only (Table 2); the abundances of Mediomastus and Syllis were too low in the Perumytilus and Semimytilus habitats, respectively, to make a meaningful comparison. Comparison of the 5 taxa on 3 sampling occasions revealed that, for the majority of taxa, aggregation in the Perumytilus bed was significantly stronger than in the Semimytilus bed. The exceptions (i.e. no difference in $I_{\delta}$ between the 2 beds) were Lumbrineris in July (but marginally significant at $0.1>p>0.05,2$ tailed test based on Jack-knife expectations), Scoloplos in March, and Typosyllis in July. Therefore, polychaetes were more (or at least equally) patchily distributed in the Perumytilus habitat than in the Semimytilus habitat.

\section{DISCUSSION}

2 beds, e.g. Pseudonereis (Fig. 7a); (2) density is always higher in the Semimytilus than in the Perumytilus bed, e.g. Halosydna (Fig. 7b) and Typosyllis (Fig. 7f); (3) density is higher in the Semimytilus than in the Perumytilus bed on some occasions, e.g. Lumbrineris (Fig. 7c) and Mediomastus (Fig. 7e); (4) density is always higher in the Perumytilus than in the Semimytilus bed, e.g. Syllis (Fig. $7 \mathrm{~g}$ ); (5) density may/may not be higher in one bed than in another
Although polychaetes are known to occur on both hard and soft substrates, the majority of past studies on population dynamics and spatial patterns focused on species in soft-bottom environments, particularly in intertidal sand/mudflats (e.g. Woodin 1974, Reise 1979, Weinberg 1979, Whitlatch 1980, Levin 1981, 1984, Wilson 1981, Anderson \& Kendziorek 1982, Tamaki 1985a, Thrush et al. 1989). It is, however, incorrect to assume 


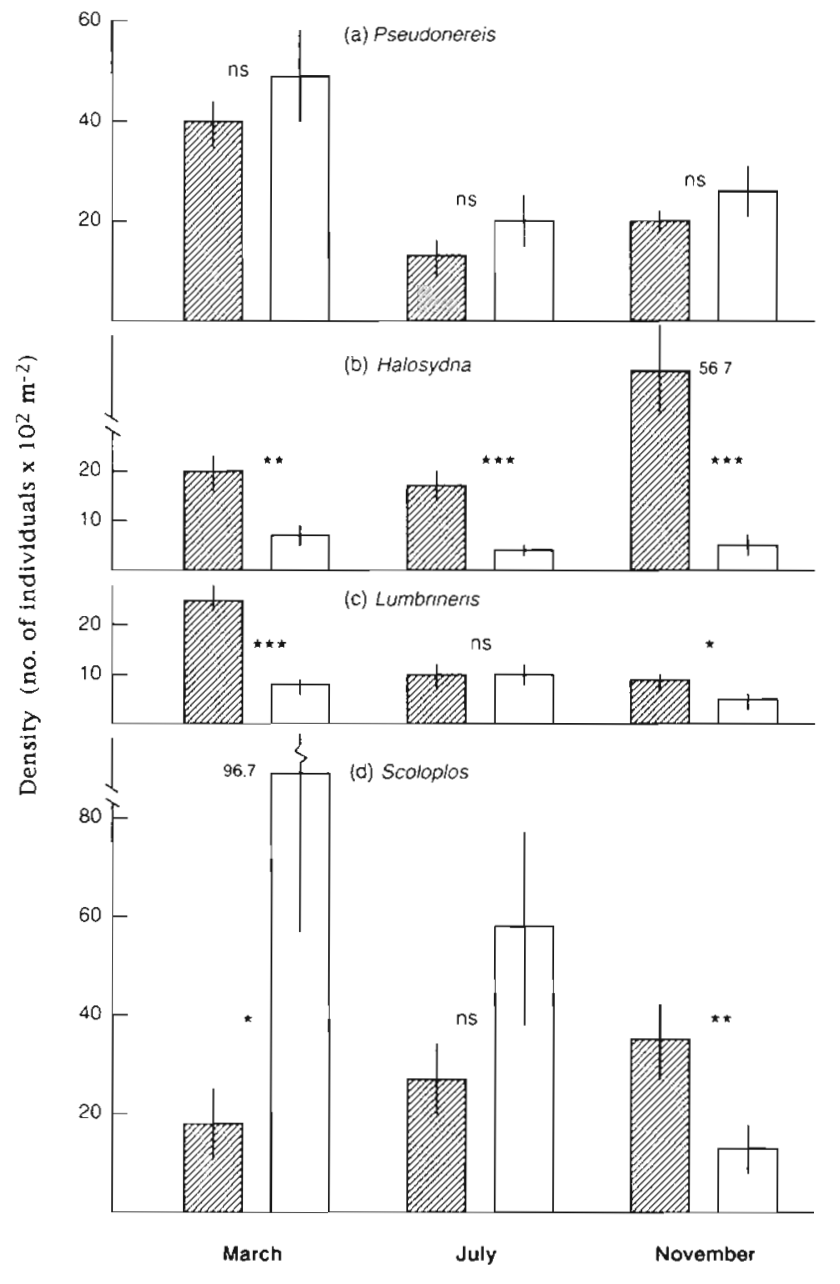

that mussel beds on hard substrates represent a less favourable habitat for polychaete species. The present study reveals that the overall abundance of polychaetes in a Semimytilus habitat may reach over 36000 ind. $\mathrm{m}^{-2}$, a density comparable to some high values observed in soft sediments (cf. Volckaert 1987). Thus, on the Pacific coast of South America, which is generally characterised by the formation of steep volcanic rock walls and, consequently, poor development of

Table 1. Morisita's index of dispersion $I_{\delta}\left(\chi^{2}\right.$ in parentheses, $\mathrm{n}=10$ ) for 6 polychaete taxa in a Perumytilus bed. All indicate a significant (at least $p<0.05$ ) contagion

\begin{tabular}{|llll|}
\hline & \multicolumn{1}{c}{ March } & \multicolumn{1}{c|}{ July } & November \\
\hline Pseudonereis & $1.33(171.4)$ & $1.49(107.0)$ & $1.37(102.1)$ \\
Halosydna & $1.17(19.4)$ & $1.28(20.2)$ & $1.48(33.4)$ \\
Lumbrineris & $1.40(32.0)$ & $1.23(31.6)$ & $1.56(35.3)$ \\
Scoloplos & $2.07(1041)$ & $1.97(565.9)$ & $2.27(165.2)$ \\
Typosyllis & $1.10(94.9)$ & $1.31(149.9)$ & $1.19(158.9)$ \\
Syllis & $1.19(33.0)$ & $1.70(54.6)$ & $1.22(29.7)$ \\
\hline
\end{tabular}
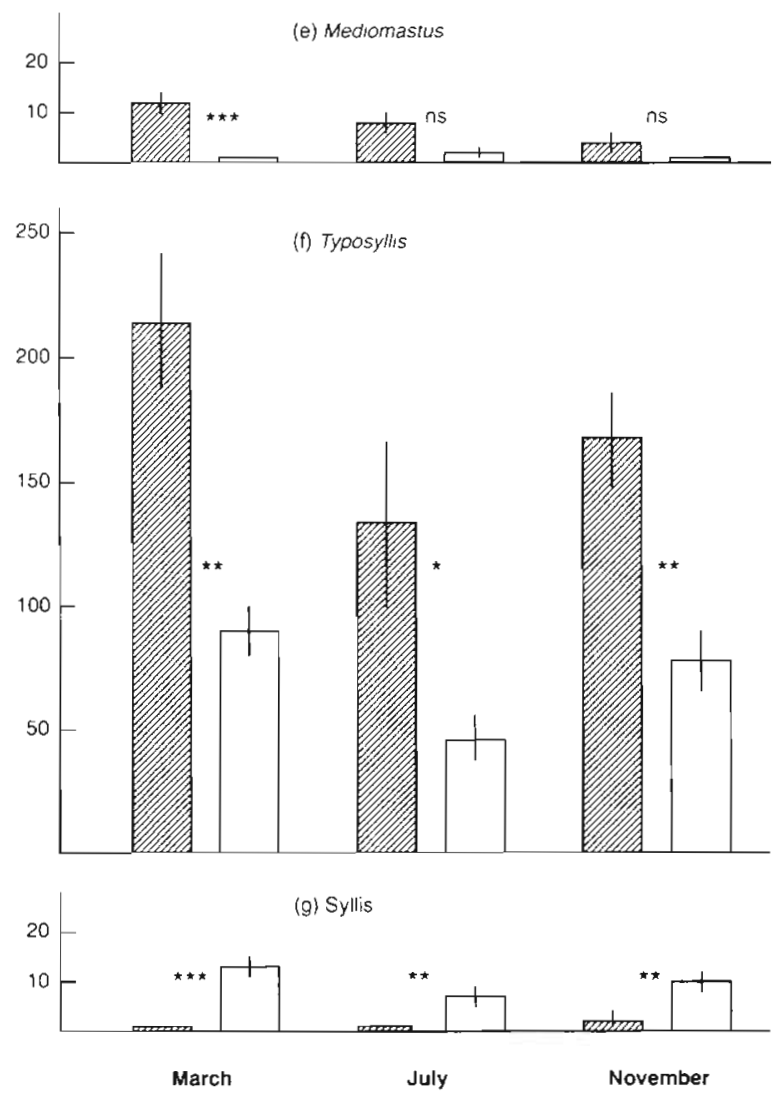

Fig. 7 Comparison of densities of different polychaete taxa between Semimytilus (hatched graph) and Perumytilus (open graph) beds on 3 occasions. Mean densities with 1 SE (vertical bar) are shown. Significant differences (ANOVA) are indicated as: $" p<0.05, \cdots p<0.01, \cdots p<0.001$, and ns: $p>0.05$

intertidal sand/mudflats, mussel beds on rocky substrates are the main habitat for many 'infaunal' polychaete species. It should be stressed here, however, that mussel beds are not an exact substitute for soft sediments but constitute a distinct habitat which is used by a distinct faunal assemblage of polychaetes. In particular, it is notable that the Semimytilus-associated

Table 2. Number of values of Morisita's index of dispersion $\left(I_{\delta}\right)$ obtained for a Semimytilus bed through a Jack-knife type procedure. Values were less than those observed for a Perumytilus bed (percentage shown in parentheses). "Significant $\left(\mathrm{p}<0.05,2\right.$-tailed test) difference in $l_{\hat{\delta}}$ between the 2 habitats (i.e. a significantly stronger aggregation in the Perumytilus bed than in the Semimytilus bed)

\begin{tabular}{|c|c|c|c|}
\hline & March & July & November \\
\hline Pseudonereis & $3003(100 \%)^{\circ}$ & $3003(100 \%)^{\circ}$ & $3003(100 \%)$ \\
\hline Halosydna & $3003(100 \%)^{\circ}$ & $3003(100 \%)^{\circ}$ & $3003(100 \%)^{\circ}$ \\
\hline Lumbrineris & $3003(100 \%)^{\circ}$ & $2905(96.7 \%)^{\mathrm{ns}}$ & $3003(100 \%)^{\circ}$ \\
\hline Scoloplos & $2273(75.7 \%)^{\mathrm{ns}}$ & $2997(99.8 \%)^{\circ}$ & $3003(100 \%)$ \\
\hline Typosyllis & $3003(100 \%)^{\circ}$ & $2349(78.2 \%)^{\mathrm{ns}}$ & $3003(100 \%)$ \\
\hline
\end{tabular}


fauna is dominated by truly free-ranging species while sedentary, tube-building or burrowing species are relatively scarce; the same pattern was seen in polychaete fauna associated with Mytilus edulis (Tsuchiya \& Nishihira 1985). This is considered to relate to the fact that mussel beds are distinctly coarse-grained habitats with variable interstitial spaces, in contrast to the fine-grained nature of soft substrates (Jumars 1975). An analogous system may be found in polychaete assemblages associated with dense tubes of reef-constructing organisms such as the polychaete Petaloproctus socialis (Wilson 1979) and vermetid gastropods Dendropoma spp. (Safriel \& Ben-Eliahu 1991), where high species richness and/or abundances of mobile species tend to occur.

The present data on seasonal population dynamics indicate that there is a general tendency toward reduced population densities in winter even within a subtropical assemblage, although overall differences between minimum and maximum densities over a 1 yr period are relatively small for all the taxa, i.e. well within 1 order of magnitude. This is considered to reflect a prolonged but pulsed reproductive cycle of many subtropical species, with peaks of juvenile recruitment in austral spring following adult mortality after spawning in late winter (e.g. Halosydna, Scoloplos and Typosyllis). This population trend coincides with the patterns observed for other, non-polychaete taxa associated with mussels on this rocky shore such as the limpet Lottia ceciliana and the ophiuroid Ophiactis kröyeri (Tokeshi \& Romero 1995a, Tokeshi pers. obs.).

Although both spring spawning and prolonged reproduction are known for some subarctic and temperate species of polychaete (e.g. Woodin 1974, Curtis 1977), such information has rarely been linked to population trends under natural conditions (cf. Sarvala 1971). In a study on the abundances of temperate polychaete species on the Pacific North American coast, Woodin (1974) reported that Lumbrineris inflata and Axiothella rubrocincta had continuous, year-long reproduction, but the population data were based on unreplicated sampling and therefore it is difficult to know precisely how such continuous reproduction affected overall population fluctuations. Nevertheless, in terms of overall densities, L. inflata in her study seems to have fluctuated between 660 and 3360 ind $\mathrm{m}^{-2}$, a range comparable to the densities observed for lumbrinerids in the present study (890 to $2610 \mathrm{~m}^{-2}$ ).

The data from the present investigation agree with those of Woodin (1974), Wilson (1979) and Tsuchiya \& Nishihira (1985) in that small-bodied species of the family Syllidae are the numerically most abundant within a polychaete assemblage. Typosyllis in the
Semimytilus bed reached $21000 \mathrm{~m}^{-2}$, a value comparable to those of up to 17500 ind. $\mathrm{m}^{-2}$ recorded for Exogone lourei (a species of Syllidae which is morphologically similar to Typosyllis) from a mudflat on a temperate Pacific North American coast (Woodin 1974). Similarly, Syllis cornuta was the most abundant species among polychaetes associated with Petaloproctus reefs on the Atlantic coast of North America (Wilson 1979) and Typosyllis adamanteus krilensis numerically dominated a polychaete assemblage associated with Mytilus edulis on the Pacific coast of Japan (Tsuchiya \& Nishihira 1985). Apart from soft substrates, species of this family are particularly known to be closely associated with macroalgae (particularly holdfasts), stony substrates and various structures formed by sedentary animals, e.g. ascidians, bryozoans, sponges and corals. These habitats have traditionally been overlooked in ecological studies of polychaetes, with a consequence that the abundances of Syllidae in marine benthic systems may not be sufficiently appreciated.

It has recently been argued that population density is either negatively related to body size or peaks at a low value of body size and thereafter declines in a species assemblage (Lawton 1989, Blackburn et al. 1993). This pattern is particularly evident when an assemblage encompasses a wide range (taxonomically distant) of taxa (Damuth 1981, 1987). An important question is whether a 'density-body size allometry' would apply to a taxonomically closer and ecologically tighter assemblage, which would then give at least a partial explanation of patterns of resource allocation within an assemblage in question (Tokeshi 1993). The polychaete assemblage in the present study does not seem to demonstrate such an allometric relationship, suggesting that body size is insufficient to explain abundances of different taxa.

Analysis of dispersion patterns has revealed that all the taxa had a significantly clumped or contagious distribution on all occasions, though the degree of aggregation varied among different taxa. Within a taxon, seasonal variability in $I_{\delta}$ was relatively low (the only exception being Mediomastus), indicating that each taxon tends to maintain a similar pattern of dispersion throughout a year. Furthermore, $\dot{m}-m$ analysis showed that a taxon-specific dispersion pattern persisted across different densities and through time in Pseudonereis, Halosydna, Lumbrineris and Scoloplos. It is interesting to note that the most abundant and the least abundant taxa in this assemblage, Typosyllis and Mediomastus, respectively, had a non-significant $\dot{m}-m$ relation. The latter may have been subject to haphazard variation in $\dot{m}$ (and $I_{\delta}$ ) due to low mean densities (all the observed values $<2000$ ind. $\mathrm{m}^{-2}$ ), while results for the former may indicate a truly constant nature of $\dot{m}$ in this abundant species or alternatively, a chance. 
It should be stressed here that the results observed in this study refer only to a scale of $0.01 \mathrm{~m}^{2}$, since it has increasingly been recognised that patterns of dispersion are largely dependent upon spatial scales of investigation (Thrush 1991). Nevertheless, it is notable that no regular dispersion pattern has been detected among a total of 54 datasets ( 36 from the Semimytilus bed and 18 from the Perumytilus bed) in this polychaete assemblage. Past studies reported the occurrence of a regular distribution in some tube-dwelling species, e.g. Nereis diversicolor (Reise 1979), Pseudopolydora paucibranchiata (Levin 1981) and Thelepus crispus (Anderson \& Kendziorek 1982). The results of the present study give credence to the view that freeranging polychaetes are non-territorial and tend to be contagiously distributed, perhaps responding to heterogeneity in microhabitat environments and resource availability rather than being influenced by intraspecific interactions. Tamaki (1985b) noted the lack of intraspecific interference in the mobile, deposit-feeding polychaete Armandia sp. (Opheliidae) in a laboratory experiment.

The existence of the Perumytilus bed just above the the Semimytilus bed offered an opportunity to examine the variation in spatial patterns of intertidal polychaetes under different conditions. The lower Semimytilus bed appeared to be a more favourable habitat for polychaetes with respect to the availability of refuges and habitable space, frequency of food supply by surf, and the lower risk of heat and desiccation, as shown by significantly higher densities in the Semimytilus than in the Perumytilus bed for a number of taxa. Higher abundance in the Semimytilus habitat was particularly evident in Halosydna and Typosyllis, the 2 taxa with a completely free-living mode of life. On the other hand, it is notable that Syllis demonstrated an opposite trend, i.e. being more abundant in the Perumytilus than in the Semimytilus bed. It is possible that this medium-sized (body length ca $20 \mathrm{~mm}$ ) taxon is competitively excluded from the Semimytilus habitat by other free-ranging polychaetes, particularly Halosydna and Typosyllis, which occupy the same niche.

It is notable that 2 deposit-feeding taxa with limited mobility, Mediomastus and Scoloplos, were more strongly aggregated (i.e. high values of $I_{\delta}$ ) than other free rangers in the Semimytilus bed. Mediomastus was virtually absent from the upper Perumytilus bed, while Scoloplos maintained its tendency of strong aggregation there. In contrast, Halosydna, a free-ranging predator, had a relatively weak tendency of contagious distribution in both habitats. Thus, polychaetes occurring in the 2 adjacent mussel beds can be ranked in terms of dispersion tendencies, with Scoloplos demonstrating a consistent aggregative tendency whilst other
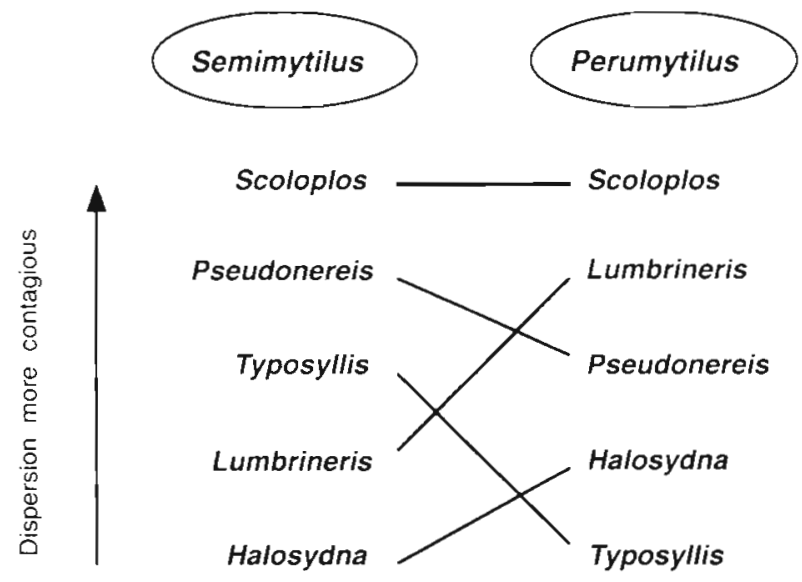

Fig. 8. Ranking of contagiousness in dispersion among 5 polychaete taxa in Semimytilus and Perumytilus beds

taxa are somewhat more variable between the 2 habitats (Fig. 8).

Comparison of Morisita's index $I_{\delta}$ between the 2 habitats clearly demonstrated that polychaetes are more patchily distributed in the Perumytilus bed. This is likely to result from high variability in microhabitat conditions and a patchy occurrence of relatively favourable spots in the Perumytilus bed. This seems to give weight to the view that benthic organisms tend to be more contagiously distributed in less favourable habitats.

In conclusion, subtle differences and variability in dispersion patterns among taxa occur as a result of interactions between behaviours and environmental conditions. Mussel beds possess complex, coarsegrained habitat structures which are considered to support high abundances and species richness of polychaetes, leading to the demonstration of taxa-specific dispersion patterns. Comparative studies of such patterns in mussel beds from different parts of the world would be highly illuminating.

Acknowledgements. This study was made possible by generous help from many individuals in the Zoology Laboratory, Universidad Nacional Mayor de San Marcos, Lima, Peru. I am grateful to Leonardo Romero for assistance in the field and to Elba Canahuire, César Córdova, Carlota Estrella, Teresa Jerí, Domingo Iparraguirre, Oswaldo Cornejo, Guillermo Llerena, and Drs Juan Tarazona and Carlos Paredes for the provision of facilities and for the solving of various logistic problems in the laboratory. The study was partially funded by a grant from the Agency for International Development, USA, and carried out whilst I was 'Profesor Invitado' at the Facultad de Ciencias Biológicas, UNMSM. This paper is dedicated to the memory of Nelida 'Silvana' Tejada de Córdova, who was a promising young scientist and shared with us the joys and hardships of working in Ancón and in the Ciudad Universitaria. 


\section{LITERATURE CITED}

Alveal K, Romo H, Valenzuela J (1973) Consideraciónes ecológicas de las regiones de Valparaiso y de Magallanes. Rev Biol Mar 15:1-29

Anderson DJ, Kendziorek M (1982) Spacing patterns in terebellid polychaetes. J exp mar Biol Ecol 58:193-205

Begon M, Harper JH, Townsend CR (1990) Ecology: individuals, populations and communities. Blackwell Scientific Publications, Oxford

Blackburn TM, Brown VK, Doube B (1993) The relationship between body size and abundance in natural animal assemblages. J Anim Ecol 62:519-528

Castilla JC (1981) Perspectivas de investigación en estructura y dinámica de comunidades intermareares rocosas de Chile central. II. Depredadores de alto nivel trófico. Medio Ambiente Esp 5:190-215

Chalmer PN (1982) Settlement patterns of species in a marine fouling community and some mechanisms of succession. J exp mar Biol Ecol 58:73-85

Curtis MA (1977) Life cycles and population dynamics of marine benthic polychaetes from the Disco Bay area of West Greenland. Ophelia 16:9-58

Damuth $J$ (1981) Population density and body size in mammals. Nature 290:699-700

Damuth J (1987) Interspecific allometry of population density in mammals and other animals: the independence of body mass and population energy use. Biol $\mathrm{J}$ Linn Soc 31 . $193-246$

Dayton PK (1971) Competition, disturbance and community organization: the provision and subsequent utilization of space in a rocky intertidal community. Ecol Monogr 41 . $351-389$

Dean TA, Hurd LE (1980) Development in an estuarine fouling community: the influence of early colonists on later arrivals. Oecologia 46:295-301

Eckman JE (1979) Small-scale patterns and processes in a soft-substratum, intertidal community. J mar Res 37: $437-457$

Greene $\mathrm{CH}$, Schoener A (1982) Succession on marine hard substrata: a fixed lottery. Oecologia 55:289-297

Iwao S (1968) A new regression method for analyzing the aggregation pattern of animal populations. Res Populat Ecol 10:1-20

Iwao S (1972) Application of the $\dot{m}-m$ method to the analysis of spatial patterns by changing the quadrat size. Res Popul Ecol 14:97-128

Jumars PA (1975) Environmental grain and polychaete species' diversity in a bathyal benthic community. Mar Biol 30:253-266

Jumars PA (1978) Spatial autocorrelation with RUM (Remote Underwater Manipulator): vertical and horizontal structure of a bathyal benthic community. Deep Sea Res 25: $589-604$

Lawton JH (1989) What is the relationship between population density and body size in animals? Oikos 55:429-434

Levin LA (1981.) Dispersion, feeding behavior and competition in two spionid polychaetes. $J$ mar Res 39:99-117

Levin LA (1984) Life histories and dispersal patterns in a dense infaunal polychaete assemblage: community structure and response to disturbance. Ecology 65:1185-1200

Lloyd M (1967) Mean crowding. J Anim Ecol 36:1-30

Morisita M (1959) Measuring the dispersion of individuals and analysis of the distributional patterns. Mem Fac Sci Kyushu Univ, Ser E 2:215-235

Morisita M (1962) I $\delta_{\delta}$-index, a measure of dispersion of individuals. Res Popul Ecol 4:1-7
Okamura B (1986) Formation and disruption of aggregations of Mytilus edulis in the fouling community of San Francisco Bay, California. Mar Ecol Prog Ser 30:275-282

Paine RT (1971) A short-term experimental investigation of resource partitioning in a New Zealand rocky intertidal habitat. Ecology 52:1096-1106

Paine RT (1974) Intertidal community structure: experimental studies on the relationship between a dominant competitor and its principal predator. Oecologia 15:93-120

Paine RT, Levin SA (1981) Intertidal landscapes: disturbance and the dynamics of pattern. Ecol Monogr 51:145-178

Paredes C (1974) El modelo de zonación en el orilla rocosa del departamento de Lima. Rev Per Biol 1:168-191

Paredes C, Tarazona J (1980) Las comunidades de mitilidos del mediolitoral rocoso del departamento de Lima. Rev Per Biol 2:59-71

Pielou EC (1977) An introduction to mathematical ecology. Wiley-Interscience, New York

Reise K (1979) Spatial configurations generated by motile benthic polychaetes. Helgoländer wiss Meeresunters 32: $55-72$

Safriel UN, Ben-Eliahu MN (1991) The influence of habitat structure and environmental stability on the species diversity of polychaetes in vermetid reefs. In: Bell SS, McCoy ED, Mshinsky HR (eds) Habitat structure: the physical arrangement of objects in space. Chapman \& Hall, London, p 349-369

Sarvala J (1971) Ecology of Harmothoe sarsi (Malmgren) (Polychaeta, Polynoidae) in the northern Baltic area. Ann Zool Fenn 8:231-309

Schoener A, Schoener TW (1981) The dynamics of the species-area relationship in marine fouling systems: 1 . Biological correlates of changes in the species-area slope. Am Nat 118:339-360

Seed R (1976) Ecology. In: Bayne BL (ed) Marine mussels: their ecology and physiology. Cambridge University Press, Cambridge, p 13-65

Seed R, Suchanek TH (1992) Population and community ecology of Mytilus. In: Gosling E (ed) The mussel Mytilus: ecology, physiology, genetics and culture. Elsevier, Amsterdam, p 87-169

Suchanek TH (1979) The Mytilus californianus community: studies on the composition, structure, organization, and dynamics of a mussel bed. PhD thesis, University of Washington. Seattle

Suchanek TH (1985) Mussels and their role in structuring rocky shore communities. In: Moore $\mathrm{PG}$, Seed R (eds) The ecology of rocky coasts. Hodder and Stoughton, Sevenoaks, p $70-96$

Tamaki A (1985a) Inhibition of larval recruitment of Armandia sp. (Polychaeta: Opheliidae) by established adults of Pseudopolydora paucibranchiata (Okuda) (Polychaeta: Spionidae) on an intertidal sand flat. J exp mar Biol Ecol $87: 67-82$

Tamaki A (1985b) Detection of non-interference within a mobile polychaete species. J exp mar Biol Ecol 90:277-287

Thrush SF (1991) Spatial patterns in soft-bottom communities. Trends Ecol Evol 6:75-78

Thrush SF, Hewitt JE, Pridmore RD (1989) Patterns in the spatial arrangements of polychaetes and bivalves in intertidal sandflats. Mar Biol 102:529-535

Tokeshi M (1989) Development of a foraging model for a field population of the South Amencan sun-star, Heliaster helianthus. J Anim Ecol 58:189-206

Tokeshi M (1991) Extraoral and intraoral feeding: flexible foraging tactics in the South American sun-star, Heliaster helianthus. J Zool 225:339-347 
Tokeshi M (1993) Species abundance patterns and community structure. Adv ecol Res 24:111-186

Tokeshi $M$ (1995) On the mathematical basis of the variancemean power relationship. Res Populat Ecol (in press)

Tokeshi M. Estrella C, Paredes C (1989a) Feeding ecology of a size-structured predator population, the South American sun-star Heliaster helianthus. Mar Biol 100: 495-505

Tokeshi M, Romero L (1995a) Filling a gap: dynamics of space occupancy on a mussel-dominated subtropical rocky shore. Mar Ecol Prog Ser 119:167-176

Tokeshi M, Romero L (1995b) Quantitative analysis of foraging behaviour in a field population of the South American sun-star, Heliaster helianthus. Mar Biol 122:297-303

Tokeshi M, Romero L, Tarazona J (1989b) Spatial coexistence of mussel-associated, free-ranging polychaetes in a subtropical intertidal habitat. J Anim Ecol 58:681-692

Tsuchiya M, Bellan-Santini D (1989) Vertical distribution of shallow rocky shore organisms and community structure of mussel beds (Mytilus galloprovincialis) along the coast of Marseille, France. Mesogée 49:91-110

Tsuchiya M, Nishihira M (1985) Islands of Mytilus as habitat for small intertidal animals: effect of island size on community structure. Mar Ecol Prog Ser 25:71-81

This article was submitted to the editor
Tsuchiya M, Nishihira M (1986) Islands of Mytilus as habitat for small intertidal animals: effect of Mytilus age structure on the species composition of the associated fauna and community organization. Mar Ecol Prog Ser 31:171-178

Volckaert F (1987) Spatial pattern of soft-bottom Polychaeta of Nova Scotia, Canada. Mar Biol 93:627-639

Weinberg JR (1979) Ecological determinants of Spionid distributions within dense patches of deposit-feeding polychaete Axiothella rubrocincta. Mar Ecol Prog Ser 1: $301-314$

Whitlatch RB (1980) Patterns of resource utilization and coexistence in marine intertidal deposit-feeding communities. $\mathrm{J}$ mar Res 38:743-765

Wilson WH Jr (1979) Community structure and species diversity of the sedimentary reefs constructed by Petaloproctus socialis (Polychaeta: Maldanidae). J mar Res 37:623-641

Wilson WH Jr (1981) Sediment-mediated interactions in a densely populated infaunal assemblage: the effects of the polychaete Abarenicola pacifica. J mar Res 39:735-748

Woodin SA (1974) Polychaete abundance patterns in a marine soft-sediment environment: the importance of biological interactions. Ecol Monogr 44:171-187

Zahl S (1977) Jackknifing an index of diversity. Ecology 58: 907-913

Manuscript first received: January 17, 1995

Revised version accepted: March 27, 1995 